\title{
Drought Analysis of Iğdır Turkey
}

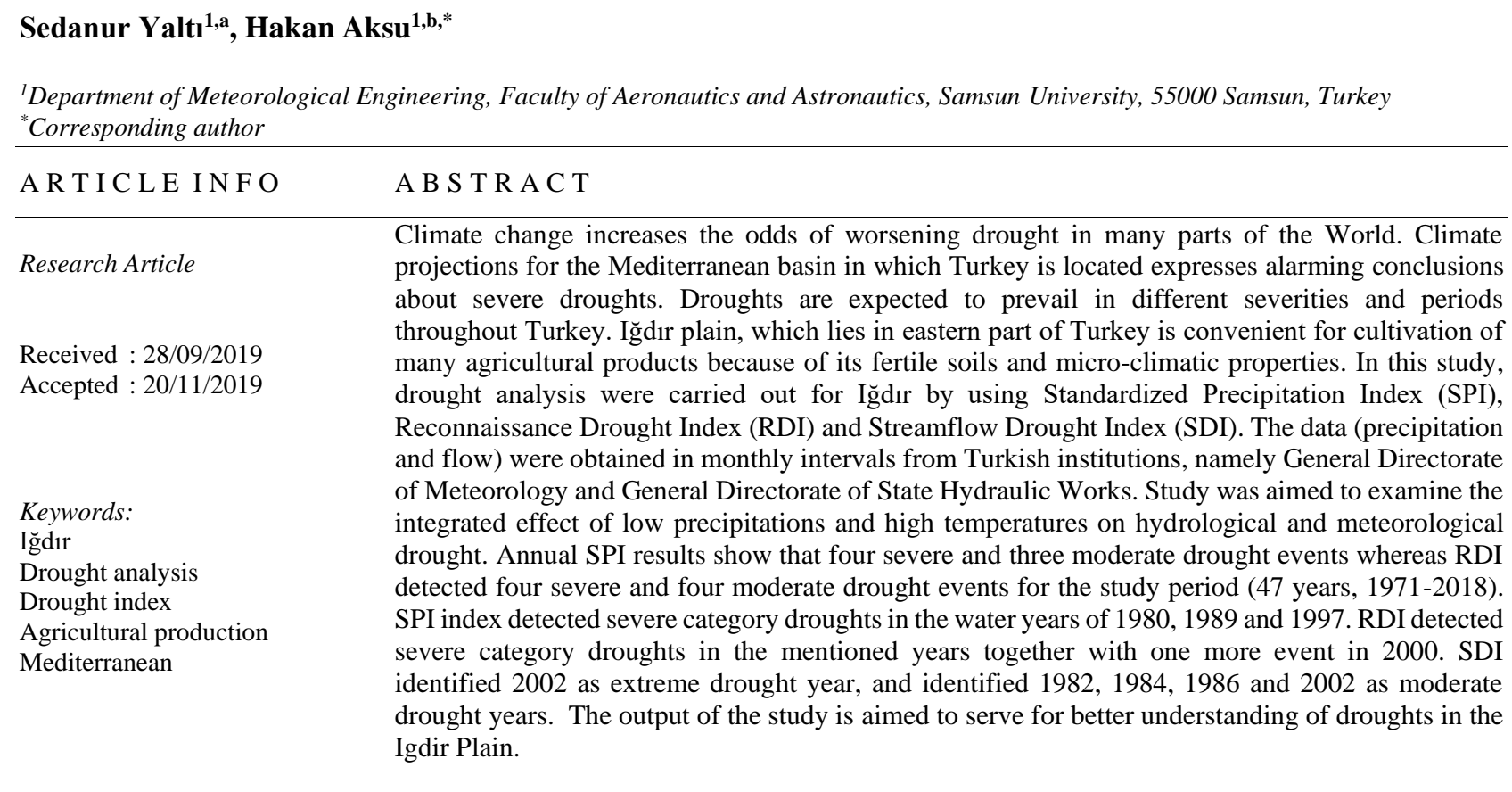

\section{Introduction}

"Drought is an insidious natural hazard that results in a deficiency of precipitation from expected or 'normal' that, when extended over a season or longer, is insufficient to meet the demands of human activities and the environment" (Wilhite and Buchanan-Smith, 2005). Main characteristics of a drought can be summarized as severity, duration, intensity and spatial extent.

Drought effects all human life and grouping of drought is mainly based on the effects of it. American Meteorology Society (2004) proposed four main groups: a) Meteorological drought can be defined as the shortage of precipitation over an area for a determined period. b) Hydrological drought can be expressed as the deficiency of surface and groundwater resources. c)Agricultural drought is related with the lack of soil moisture which causes crop failure. d) Socio-economic drought occurs when the water resources system can't support the human needs (drinking and industrial water supply, hydro-energy, agriculture etc).

Because drought is a natural climatic phenomenon and has many adverse effects on life, it is crucial to have drought management plan. The first step of these plans is the analysis of drought conditions. So far, many drought indices have been proposed in order to identify drought such as Standardized Precipitation Index (SPI) (McKee et al., 1993), China-Z index (CZI) (Wu et al., 2001), Streamflow Drought Index (SDI) (Nalbantis and Tsakiris, 2008), Palmer Drought Severity Index (PDSI) (Palmer, 1965) and Reconnaissance Drought Index (RDI) (Tsakaris and Vangalis, 2005). A brief review of drought indices can be found Handbook of Drought Indicators and Indices explaining the type (meteorological, hydrological, remote sensing or composite), input parameters, strengths and weaknesses (WMO, 2016).

Drought is a well-known characteristic of Turkey's climate. The areal annual average precipitation over Turkey is $574 \mathrm{~mm}$ whereas maximum is $25 \%$ higher and minimum is $22 \%$ lower for the period of 1981-2010 (Selek and Aksu, 2019). Many severe drought periods which caused famines, diseases and migration have been experienced in Anatolia. Over the last 40 years, the longest 
and the most severe drought events occurred between the years 1971-1974, 1983-1984, 1989-1990, 1996-2001, and 2007-2008 (Kurnaz 2014). Although many studies have been conducted for the analysis of drought conditions in some parts of Turkey (Erinç, 1949; Sırdaş, 2002; Keskin et al. 2007; Türkeş and Tatl1, 2008; Apak, 2009; Cetin at al., 2018; Çavus and Aksoy, 2019), there are very limited number of studies focusing especially on Iğdır. In $2007-$ 2008 period, Turkey has experienced severe drought conditions and one of the negative effects of these events was mainly on agricultural production. So, drought and agricultural production relation is another important aspect which must be studied in detail. As an example, the wheat production of Turkey was $21.5 \times 10^{6}$ tons in the year of 2005 , it was $17,234,000$ tons in 2007 and 17,782,000 tons in 2008 (aproximately 20\% less) as regards to severe drought conditions prevailed over Turkey (Şimşek and Çakmak, 2010).

Study area (Iğdır) is located in the eastern part of Anatolia has micro-climatic conditions convenient for agricultural production so that the area is known as eastern Çukurova and farmers cultivate very diverse agricultural products (every kind of cereals, fruits, vegetables, walnut, cotton etc). Iğdır city has 118,500 hectare fertile agricultural lands.

In this study, SPI, RDI and SDI drought indices were calculated to evaluate drought conditions over Iğdır. Precipitation, temperature and naturalized streamflow data was used to figure out the relation between meteorological and hydrological droughts in monthly time scale and water year format. Water year is the timespan between $1^{\text {st }}$ October to $30^{\text {th }}$ September for northern hemisphere. All three drought indices were calculated based on water year time format and each index value are comparable with each other.

\section{Material and Method}

\section{Study Area and Data}

Iğdır is a border city of Turkey with three countries (Armenia, Nahcivan and Iran) (Figure 1). Neighbouring cities are Erzurum, Ağrı, Kars and elevation of these cities are $1.900,1.640,1.760$ meters respectively. The elevation of Iğdır meteorology station located at the center of Iğdır is 856 meters. The elevation difference between Iğdır plain and surrounding mountainous area is the main reason of the micro-climatic characteristic of the region. According to the Köppen-Geiger climate system, climate of Iğdır is categorized as sub-tropical steppe climate (Bsk) whereas the Erzurum and Kars are cities categorized with their cold snowy forest climate humid in all seasons (humid microthermal) $D f$ (mostly $D f b$ ) (Türkeş 2019).

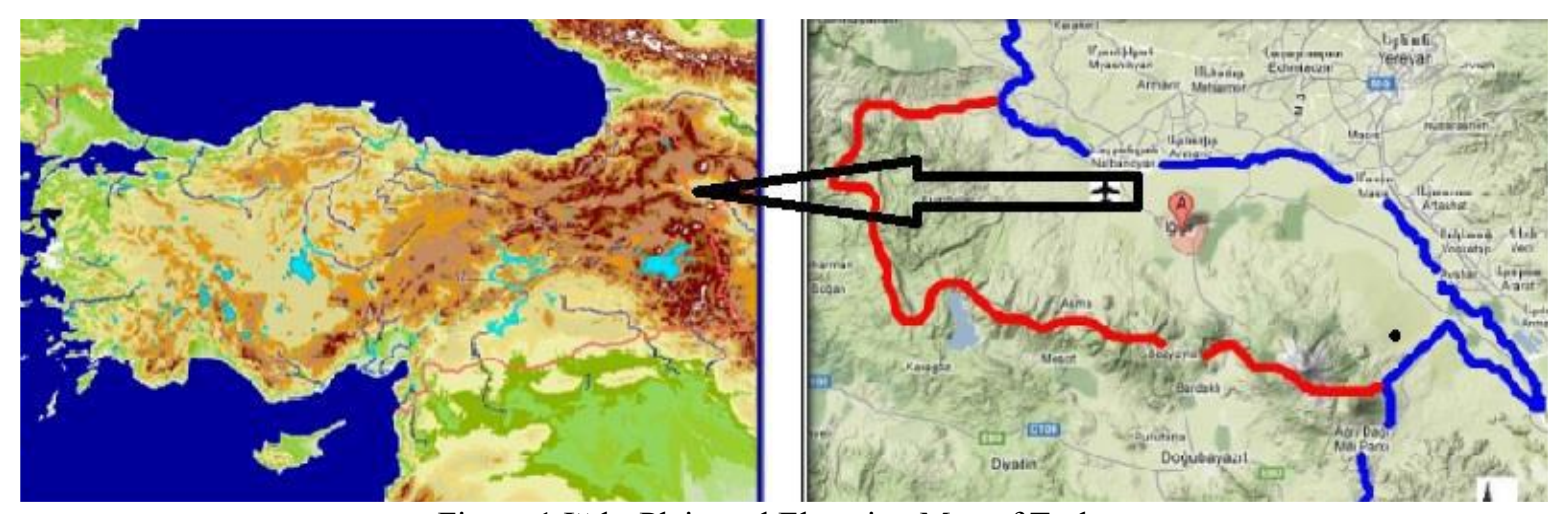

Figure 1 Iğdır Plain and Elevation Map of Turkey

Iğdır meteorology station is the only one, which has a long term meteorological records in the plain. Monthly total precipitation and monthly average temperature data were used between (1971-2018). Stream gauging stations data (station ID: E24A009 and E24A018) were analysed (normalized monthly total flow data between 1981-2011). Normalization is based on the logarithmic transformation of flow data. All the data were converted in the water year format. Yearly wheat productivity per hectare values were obtained from Turkish Statistical Institution for the period of 2004-2018.

\section{Methodology}

SPI, RDI and SDI drought indices were calculated to evaluate drought conditions over Iğdır. Indices were calculated as monthly, 3-month and yearly basis by DrinC program (Tigkas et al., 2015).

DrinC (Drought Indices Calculator) is a free software package to calculate SPI, RDI, SDI and PN drought indices. Potential evapotranspiration can be estimated by
Hargreaves (Hargreaves and Samani 1985), Thornthwaite (1948) and Blaney-Criddle (Blaney and Criddle 1950) methods. DrinC is a visual basic program and runs on Ms Windows, user friendly and has many graphical interfaces. DrinC can be used for drought identification, monitoring, and determination of areal extent of droughts.

Standardize Precipitation Index (SPI) was proposed by Mckee et al. (1993). The advantage of the method is that the input parameter is limited solely with monthly total precipitation. SPI corresponds to $\mathrm{z}$ score, expresses the distance from the mean as standart deviation unit. For this reason, SPI can be used to assess the areal extent of droughts. Precipitation data is fitted to a probability distribution and then transformed to a normal distribution. Mean values correspond to average situation whereas positive and negative values show high and low precipitations respectively. Thom (1958) proposed Gamma distribution for historical precipitation time series. Probability density function of Gamma distribution is defined as: 


$$
\mathrm{g}(\mathrm{x})=\frac{1}{\beta^{\alpha} \Gamma(\alpha)} \mathrm{x}^{\alpha-1} \mathrm{e}^{-\mathrm{x} / \beta}, \text { for } \mathrm{x}>0
$$

where; $\alpha$ is shape parameter, $\beta$ is scale parameter, $\mathrm{x}$ is precipitation amount, $\Gamma(\alpha)$ is Gamma Function. $\alpha$ and $\beta$ parameters can be estimated by Maximum likelihood:

$$
\mathrm{a}=\frac{1}{4 \mathrm{~A}}\left(1+\sqrt{1+\frac{4 \mathrm{~A}}{3}}\right), \beta=\frac{\overline{\mathrm{x}}}{\mathrm{a}}, \text { where } \mathrm{A}=\operatorname{In}(\overline{\mathrm{x}})-\frac{\sum \ln (\mathrm{x})}{\mathrm{n}}
$$

Then cumulative probability function is calculated for a given period $(1,2,6,9,12,24$ months). If the precipitation data series have zero values, then cumulative probability becomes as follows:

$$
H(x)=q+(1-q) G(x)
$$

The cumulative probability $\mathrm{H}(\mathrm{x})$ is then transformed to the standard normal random variable $\mathrm{z}$ with mean zero and variance of one (Abramovitz and Stegun, 1965).

The Reconnaissance Drought Index (RDI) (Tsakaris and Vangalis, 2005) is calculated by monthly precipitation and potential evapotranspiration values for different time scales. The potential evapotranspiration is computed by the Thornthwaite formula in this study. Initially, $\alpha_{k}$ is presented as the coefficient of the $\mathrm{i}^{\text {th }}$ year in an aggregated form using a monthly time step, and can be calculated on a monthly, seasonal or annual basis as the following:

$$
a_{k}^{(i)}=\frac{\sum_{j=1}^{k} P P_{i j}}{\sum_{j=1}^{k} E T_{i j}}, i=1: N \text { and } j=1: k
$$

where; $P_{i j}$ is precipitation, $E T_{i j}$ is potential evapotranspiration in jth month of ith year.

Normalized RDI (RDIn) is calculated by utilizing the arithmetic mean of $\bar{\alpha}_{0}$ values calculated for the $\mathrm{N}$ years of data as given below:

$$
\operatorname{RDI}_{\mathrm{n}}^{\mathrm{i}}=\frac{\mathrm{a}_{0}^{\mathrm{i}}}{\bar{\alpha}_{0}}-1
$$

Standardized RDI (RDIst) is calculated, using the following equation for each period:

$$
\operatorname{RDI}_{\mathrm{st}}^{\mathrm{i}}=\frac{\mathrm{y}^{\mathrm{i}}-\mathrm{y}_{\text {ort }}}{\sigma_{\mathrm{y}}}
$$

Where, $y^{i}$ is the $\ln a_{k}^{(i)}, y_{\text {ort }}$ is its arithmetic mean and $\sigma \mathrm{y}$ is its standard deviation.

Standardized RDI was used in order to estimate cumulative distribution function of short time period data series including zero values.

Drought severity can be categorised in mild $(-0.5$ to $-1.0)$, moderate $(-1.0$ to -1.5$)$, severe $(-1.5$ to -2.0$)$ and extreme classes $(<-2.0)$.

Potential evapotranspiration is calculated by Thornthwaite method (1948):

$$
\mathrm{PET}=16 \times(10 \times \mathrm{t} / \mathrm{l}) \alpha \times \mathrm{G}
$$

where, PET is monthly evapotranspiration, $\mathrm{t}$ is monthly average temperature $\left({ }^{\circ} \mathrm{C}\right), 1$ is annual heat index, and $\mathrm{G}$ is latitute correction.

$$
\begin{aligned}
& \alpha: 6,75 \times 10-7 \times \mathrm{I} 3-7,71 \times 10-5 \times \mathrm{I} 2+1,79 \times 10-2 \times \mathrm{I}+0,432 \\
& \mathrm{l}=\sum_{1}^{12} \mathrm{i} \\
& \mathrm{i}=(\mathrm{t} / 5) 1.51
\end{aligned}
$$

Streamflow drought index (SDI) proposed by Nalbantis and Tsakaris (2008) to identify hydrological drought is as given below:

$$
V_{i, j}=\sum_{j=1}^{3 k} Q_{i, j} i=1,2, \ldots j=1,2, \ldots 12 \mathrm{k}=1,2,3,4
$$

where, Qi,j is monthly streamflow volumes, and Vi,k is the cumulative streamflow volume for the i-th hydrological year

$$
\mathrm{SDI}_{\mathrm{i}, \mathrm{k}}=\frac{\mathrm{V}_{\mathrm{i}, \mathrm{k}}-\mathrm{V}_{\mathrm{k}_{\text {ort }}}}{\mathrm{s}_{\mathrm{k}}} \mathrm{i}=1,2, \ldots, \mathrm{k}=1,2,3,4
$$

Drought categories of SDI are identical with SPI and RDI classes as given above.

\section{Results and Conclusion}

Annual SPI results show four severe and three moderate drought events for the study period (47 years, 1971-2018) whereas RDI detected four severe and four moderate (Table 1). $15 \%$ and $17 \%$ of the study area suffer from severe and moderate droughts as regards to SPI and RDI results respectively.

SPI index detected severe category droughts in the water years 1980, 1989 and 1997. RDI detected one more severe category drought in 2000 in addition to 1980, 1989 and 1997 (Figure 2 and 3). Moderate droughts were identified in 1979, 1996, 1998 and 2008 water years by SPI. Moderate drought years detected by RDI were the same with those of SPI except the one occur in 2000, which was determined as near normal in RDI. Moreover, RDI identified 2008 as moderate drought year.

No extremely meteorological drought event was detected by SPI and RDI over the study area during the study period. The longest period of drought was between 1996 and 1998 (three years) and the second longest period was 1979-1980.

SDI identified 2002 as extreme drought water year and 1982, 1984, 1986 and 2002 as moderately drought water years. It is clear that there is a lag between hydrological and meteorological droughts. For example, 1982 was moderate, 1979 was moderate and 1980 was severe drought years (Figure 7).

According to three months assessment, SPI detected January and June of 1989, as well as October-December of 2000 as extreme drought periods. RDI identified same periods together with July-September of 1994 and JanuaryMarch of 2008 (Figure 2, 3, 4).

Drought indices and agricultural productivity values were evaluated by correlation analysis but no significant correlation was found (for $10 \%$ significance level) because the agricultural productivity is not only the function of climate but also it has close link with good agricultural practices (irrigation management, fertilizer applications etc.). 
Table 1 Drought Categories SPI, RDI (1971-2018), SDI (1981-2010)

\begin{tabular}{|c|c|c|c|c|c|c|c|}
\hline Iğdır & $\begin{array}{c}\text { Extremely } \\
\text { Dry }\end{array}$ & $\begin{array}{c}\text { Severely } \\
\text { Dry }\end{array}$ & $\begin{array}{l}\text { Moderately } \\
\text { Dry }\end{array}$ & $\begin{array}{c}\text { Near } \\
\text { Normal }\end{array}$ & $\begin{array}{c}\text { Moderately } \\
\text { Wet }\end{array}$ & $\begin{array}{l}\text { Very } \\
\text { Wet }\end{array}$ & $\begin{array}{c}\text { Extremely } \\
\text { Wet }\end{array}$ \\
\hline SPI & 0 & 4 & 3 & 32 & 5 & 2 & 1 \\
\hline RDI & 0 & 4 & 4 & 31 & 6 & 1 & 1 \\
\hline SDI & 1 & 0 & 4 & 21 & 2 & 1 & 1 \\
\hline
\end{tabular}

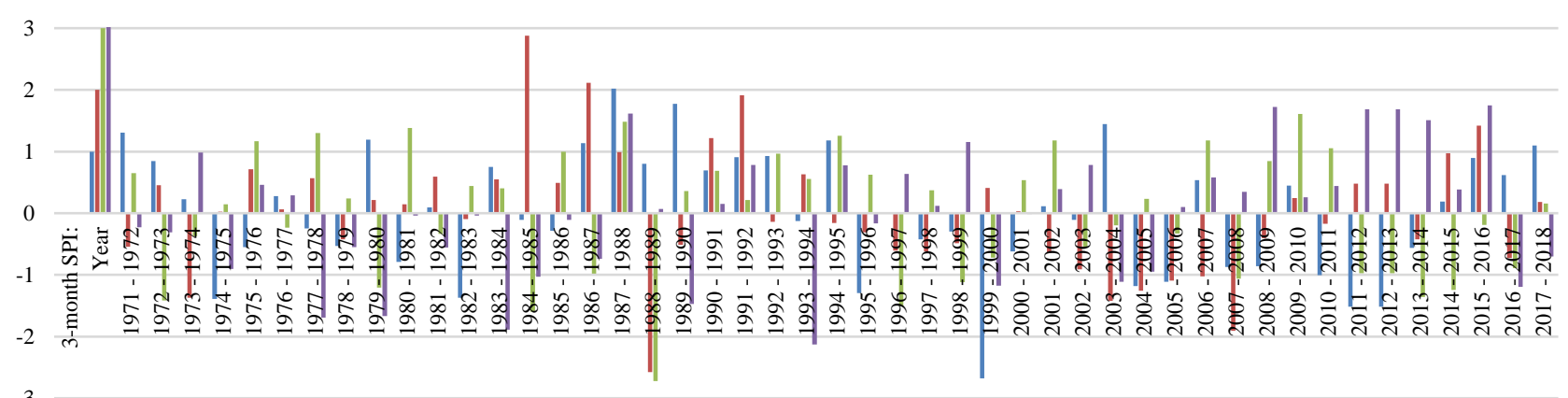

Figure 2 Three Months SPI Values

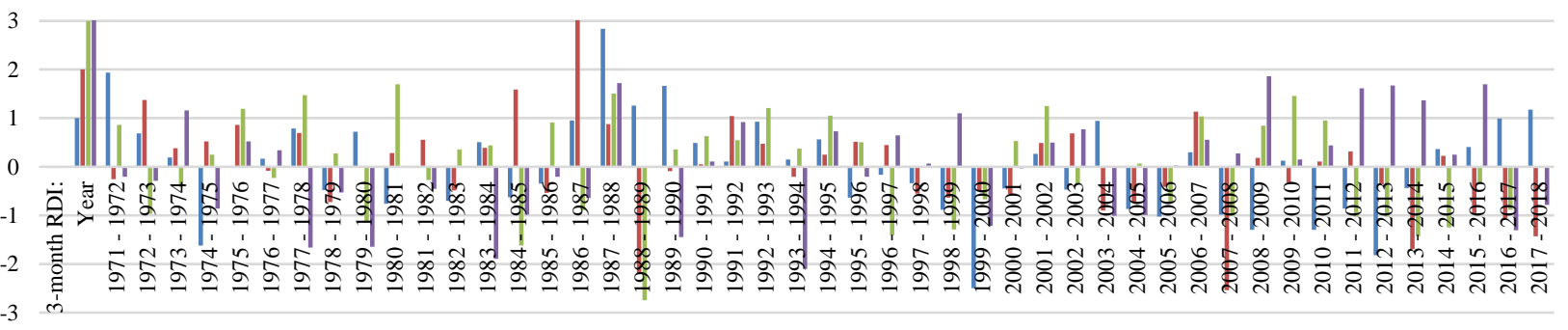

Figure 3 Three Months RDI Values

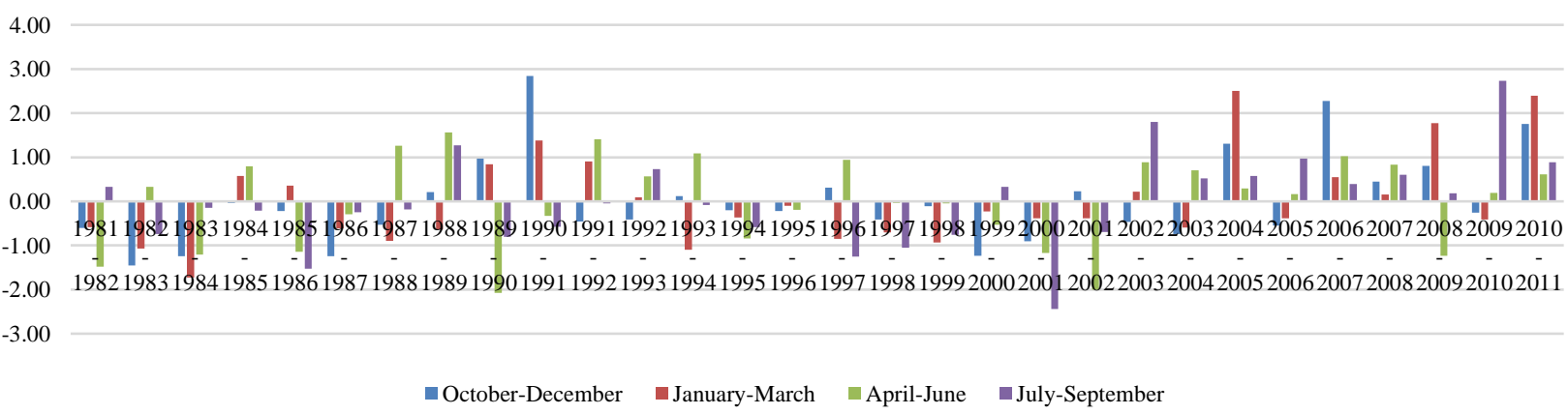

Figure 4 Three Months SDI Values

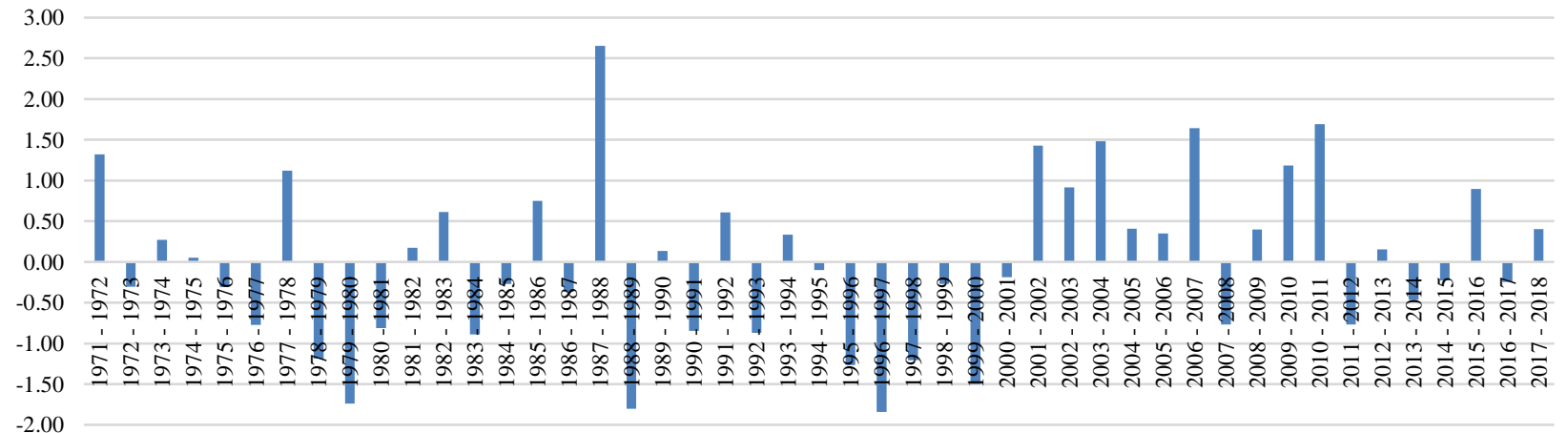

Figure 5 Annual SPI Values 


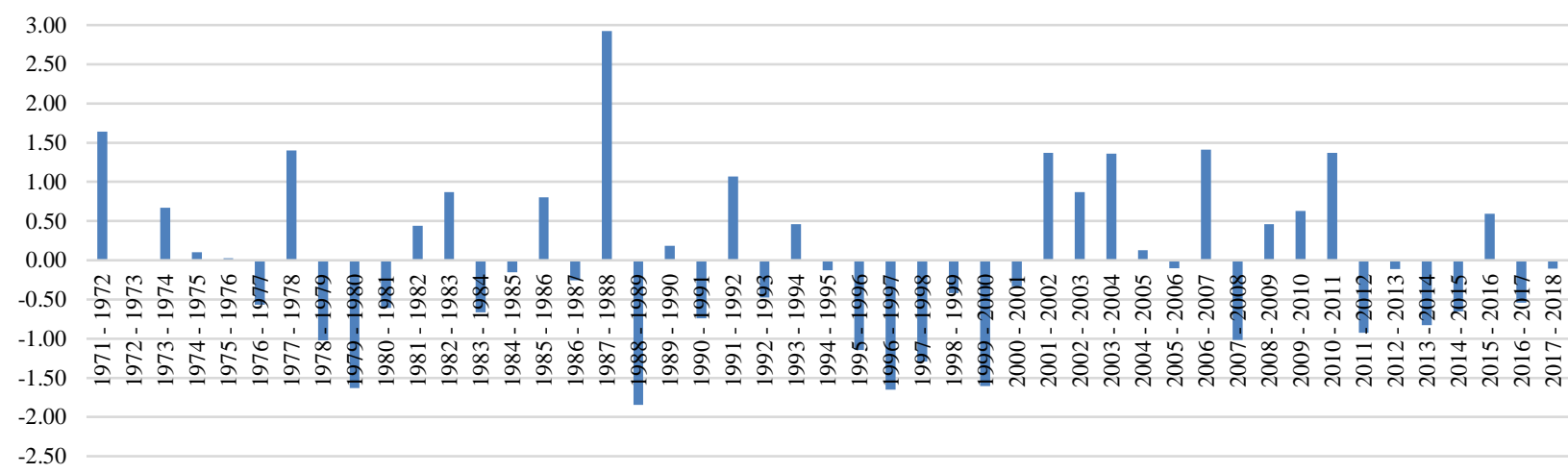

Figure 6 Annual RDI Values

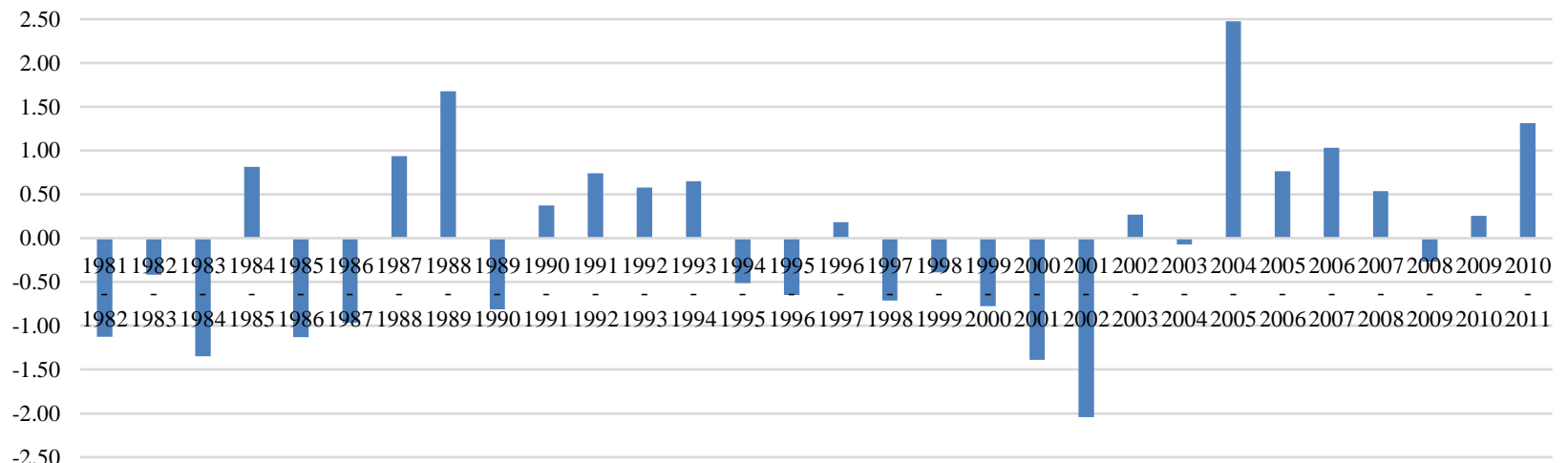

Figure 7 Annual SDI Values

Siberian High Presure (cP) is one of the major system affecting the weather conditions of Easthern Anatolia in winter and causes less precipitation. Continental tropical pressure system known as Basra Low Pressure (cT) causes convective precipitation and high temperatures in summer time. Drought can be monitored by synoptical analysis of the region. Two severe drought period detected by three month RDI calculations correspond to winter times. Future detailed studies on teleconnection patterns (NAO and AO) and Iğdır droughts may be useful for better understanding of the main drivers.

\section{References}

Abramovitz M. and Stegun I. 1965. Handbook of mathematical functions, National bureau of standards, applied mathematics series-55. Washington, D.C.

American Meteorological Society (AMS). 2004. Statement on meteorological drought. Bull. Am. Meteorol. Soc, 85: 771773.

Apak E. 2009. Standart Yağış İndeksi (SPI) Yöntemi ile Ege Bölgesinde Kuraklık Analizi. Ege Üniversitesi Fen Bilimleri Enstitüsü Yüksek Lisans Tezi. İzmir. 12-47 in Turkish.

Blaney HF, Criddle WD. 1950. Determining water requirements in irrigated areas from climatological and irrigation data. Department of Agriculture, Washington. Soil conservation service technical paper 96

Çavuş Y, Aksoy H. 2019. Spatial Drought Characterization for Seyhan River Basin in the Mediterranean Region of Turkey, Water, 11(7): 1331. https://doi.org/10.3390/w11071331.
Çetin M, Aksoy H, Önöz B, Eriş E, Yüce Mİ, Selek B, Aksu H, Burgan Hİ, Eşit M, Çavuş Y, Orta S. 2018. Deriving Accumulated Precipitation Deficits from Drought SeverityDuration-Frequency Curves: A Case Study in Adana Province, Turkey. 1st International, 14th National Congress on Agricultural Structures and Irrigation. 26-28 September 2018 Antalya. ISBN 978-605-81136-0-2, pp.39-48.

Erinç S. 1949. The climates of Turkey according to Thornthwaite's classifications. Annals of the Association of American Geographers, 39: 26-46.

Hargreaves GH, Samani ZA. 1985. Reference crop evapotranspiration from temperature, Trans ASAE 1(2): 9699.

Keskin ME, Terzi Ö, Taylan E, Yılmaz AG. 2007. Isparta bölgesi meteorolojik kuraklık analizi, I. Türkiye İklim Değişikliği Kongresi-TİKDEK 2007. İstanbul, Türkiye, 350-359 in Turkish.

Kurnaz L. 2014. Drought in Turkey, Istanbul Policy Center, p 116.

McKee TB, Doesken NJ, Kleist J. 1993. The Relationship of Drought Frequency and Duration to Time Scales, Proceedings of the 8th Conference on Applied Climatology, 17-22 January 1993, Anaheim, CA. Boston, MA, American Meteorological Society.

Nalbantis I, Tsakiris G. 2008. Assessment of hydrological drought revisited, Water Resources Management, 23(5): 881897.

Palmer WC. 1965. Meteorological Drought. Research Paper No. 45, US Weather Bureau, Washington, DC.

Selek B, Aksu H. 2019. Water Resources Potential of Turkey, In book: Water Resources of Turkey. https://doi.org/10.1007 1978-3-030-11729-0_8. 
Şimşek O, Çakmak B. 2010. Drought Analysis for 2007-2008 Agricultural Year of Turkey, Journal of Tekirdag Agricultural Faculty 7(3): 99.

Sırdaş S. 2002. Meteorolojik kuraklık modellemesi ve Türkiye uygulaması. İstanbul Teknik Üniversitesi, Fen Bilimleri Enstitüsü, Doktora Tezi, 237s. İstanbul, in Turkish.

Thom HCS. 1958. A note on the gamma distribution. MonWeather Rev 86: 117-122.

Thornthwaite CW. 1948. An approach towards a rational classification of climates. Geogr Rev 38: 55-94.

Tigkas D, Vangelis H, Tsakiris G. 2015. DrinC: a software for drought analysis based on drought indices. Earth Sci Inform 8:697-709 https://doi.org/10.1007/s12145-014-0178 .

Tsakiris G, Vangelis H. 2005. Establishing a drought index incorporating evapotranspiration. European Water, 9/10: 3-11.

Türkeş M, Tatlı H. 2008. Türkiye'de kuraklık olasılıklarının standartlaştırılmış yağış indisi (SPI) kullanılarak saptanması ve iklimsel değişkenlik açısından değerlendirilmesi. Küresel İklim Değişimi ve Su Sorunlarının Çözümünde Ormanlar Sempozyumu Bildiriler Kitabı (Ed., Ünal Akkemik), 55-62. Türkiye Ormancılar Derneği Marmara Şubesi, 13-14 Aralık 2007. Bahçeköy - İstanbul in Turkish.
Türkeş M. 2019. Climate and Drought in Turkey, In book: Water Resources of Turkey. https://doi.org/10.1007/978-3-03011729-0_4.

Wilhite DA, Buchanan-Smith M. 2005. Drought as hazard: understanding the natural and social context. In: Wilhite DA (ed) Drought and water crises: science, technology, and management issues. CRC Press, Taylor \& Francis Group, Florida, 3-29.

World Meteorological Organization (WMO) and Global Water Partnership (GWP). 2016. Handbook of Drought Indicators and Indices (M. Svoboda and B.A. Fuchs). Integrated Drought Management Programme (IDMP), Integrated Drought Management Tools and Guidelines Series 2. Geneva.

Wu H, Hayes MJ, Weiss A, Hu Q. 2001. An evaluation of the Standardized Precipitation Index, the China-Z Index and the statistical Z-score. International Journal of Climatology, 21: $745-758$. 